\title{
Exploring the Theology of Selected Hymns: Towards an African Christian Theology of Mission
}

\author{
Isaac Boaheng 1 \\ ${ }^{1}$ Department of Biblical and Religious Studies, University of the Free State, South Africa.
}

\begin{abstract}
This paper explores the theological message embedded in the hymns: "The incarnate God appeared" and "Come Holy Spirit, come now". Theological findings from these hymns are used to formulate an African Christian theology of mission based on thematic areas such as the trinitarian dimension of mission, the centrality of the cross in mission, mission as the core mandate of the Church and mission as incarnational agapaō. By this, the paper makes the message of the selected hymns accessible to the global Christian community, promotes the development of hymnody in the African church and at the same time provides a paradigm for Christian mission in the 21st century African society. This is a literature research that uses data from books, theses, journal articles, among others. The findings indicate that hymns constitute a great tool for the missionary enterprise of the church, therefore Christian hymns should be developed and promoted. It is recommended that, for Christian mission in Africa to be meaningful and relevant to Africans, it must endeavor to address the existential issue in African societies.
\end{abstract}

Correspondence:

Isaac Boaheng

Email: revisaacboaheng@gmail. com

Publication History

Received 21st September 2020, Accepted 8th January, 2021,

Published online 13th January, 2021.

Key Words: Africa, Hymns, Christology, Mission, Pneumatology, Theology

(C) 2021 The Author(s). Published and Maintained by Noyam Publishers.

This is an open access article under the CCBY license (http://creativecommons.org/licenses/by/4.0/).

\section{INTRODUCTION}

Gordon D. Fee, at a conference at the Langley Vineyard, stressed the power of hymnology to form people's theological thought, saying "show me a church's songs, and I'll show you their theology." By this assertion, Fee points out that the theology of the Christian church depends heavily on the hymns sung.This is true because as Andy Park rightly states "music is the most accessible form of communication." 3 People digest songs far more than sermons. In most churches hymn-singing plays a didactic function in corporate worship. Hymns enrich, inform, and edify believers. Therefore, a theologically weak hymn begets a theologically weak church whilst a theologically sound hymn begets a theologically sound church.

The history of the Christian church has witnessed great hymn writers such as John and Charles Wesley, Martin Luther, Isaac Watts, Edward Cooper, Gaddiel Acquaah, among others. Hymns composed by these and other hymn writers have contributed to the planting and spread of the Christian faith across the globe. Today, the church militant continues to benefit from hymns composed by the church triumphant. Whilst praising past hymn writers for their efforts, contemporary believers also have the task of adding to the church's hymns based on theological/biblical teachings and contextual issues.

This paper serves as the author's response to the Church's ${ }^{4}$ challenge of composing and exposing hymns for the benefit of the Christian community. In this paper, the author explores the theological message embedded in two of his own hymns - "The incarnate God appeared" and "Come Holy Spirit, come now" - and based on the exposition, formulates a theology of Christian mission for the African church. Consequently, the

\footnotetext{
As cited by Andy Park, To Know You More: Cultivating the Heart of the Worship Leader (Downer Grove, IL: Inter-Varsity Press, 2004), 222.

Park, To Know You More, 222.

The Church in this context is the universal Church.

These hymns have been attached to this paper in an appendix.
} 
paper does not only make the message of the selected hymns accessible to the global Christian community but also serves to provide a paradigm for Christian mission in 21st century Africa and beyond.

\section{Christological Reflections on "The incarnate God appeared"}

The hymn "The incarnate God appeared" was composed by Rev. Isaac Boaheng ${ }^{6}$ in December 2019 as a response to the various Christian messages he had preached and heard others preach during the 2019 Christmas season. When the idea of writing a hymn first occurred to Rev. Boaheng, he did not hesitate to put some words down despite his lack of formal training in hymnody. Having put down the lyrics, he sang it with a tune that he received supernaturally. Whether writing a hymn, a theological research paper, preaching, teaching, singing or undertaking any other godly task, Rev. Boaheng is motivated by the fact that "it is God who works in [humans] to will and to act in order to fulfill his [God's] good purpose" (Phil. 2:13, NIV) . The lyrics of "The incarnate God appeared" read as follows:

\section{First stanza}

The incarnate God appeared

For the salvation of man

He died on the cross, not spared

To save the repentant man

\section{Refrain}

Love that made him overcome

We strive for such wondrous love

Love that is unconditional ${ }^{8}$

Love that heals the broken heart

\section{Second stanza}

Christ is God who came in flesh

Without love he could not come

To live as God in the flesh

To make heaven our own home

\section{Refrain}

Love that made him overcome

We strive for such wondrous love

Love that is incarnational

Love that heals the broken heart

\section{Third stanza}

Humanity must respond

To such love shown by the Lord

For salvation is a bond

That brings man close to the Lord

\section{Refrain}

Love that made him overcome

We strive for such wondrous love

Love that is unconditional

Love that heals the broken heart

\section{Fourth stanza}

Sinners are always welcome

To the mercy seat of God

The Lord makes us overcome

The moment we come to God

\footnotetext{
Rev. Isaac Boaheng is an ordained minister of the Methodist Church Ghana who also serves as a Translator with the Bible Society of Ghana. He has other hymns including Who is like you?, My Lord you deserve all my praise, and teaching everyone to live like Christ, a song written in support of the 2020-2021 theme of the Methodist Church Ghana.

7 The hymn was harmonized by Mr. Solomon K. Wesley.

8 The words unconditional and incarnational alternate in the third line of the refrain.
} 


\section{Refrain \\ Love that made him overcome \\ We strive for such wondrous love \\ Love that is incarnational \\ Love that heals the broken heart}

With this brief background, the study proceeds to explore the Christological message of the hymn "The incarnate God appeared."

\section{Logos and Incarnation Christologies}

The hymn begins with the theologically pregnant assertion "The incarnate God appeared." The hymnist combines both Logos Christology (cf. John 1:1) and Incarnation Christology (cf. John 1:14) in this short line. In John 1:1, John makes the point that the Logos (the life-giving principle of the universe) was there in the beginning. The expression "In the beginning" of John 1:1 reminisces Genesis 1:1 where God is said to have created the heaven and the earth "In the beginning." For John, the Logos existed from the eternal past; the Logos does not have a beginning; the Logos predates date. John moves on to say "the Logos was with God [the Father]" (1:1b), meaning the Logos is distinct from God the Father. John moves forward to say "the Logos was God", that is, the Logos is of the same essence as the Father. To sum up, the Logos Christology of John 1:1 (which the hymn echoes) is that the Logos is coequal, coeternal, coexistent, and consubstantial with God the Father. ${ }^{9}$

In verse 14, John points out that the Logos of verse 1 became flesh and dwelt among humanity. The enfleshment of the divine Logos is what is referred to as the incarnation. Here, the Greek verb egeneto (meaning "to become") signifies an action at a point in time. Thus, the divine Logos who transcends time took on human flesh at a particular time in human history. The enfleshed Logos (identified as Christ) then appeared in glory and "made his dwelling among" humans (John 1:14, NIV). The enfleshment of the divine Logos brought two natures of Christ together in an inseparable union without mixture, a union referred to as the hypostatic union. Therefore, what the hymnist refers to as the incarnate God is Jesus Christ who added human nature to his divine nature. In this light, the first line of the hymn parallels the first line of the second stanza, "Christ is God who came in flesh."

\section{Incarnation as God's salvific plan}

The second line of stanza one-"For the salvation of man"10 - provides the reason for which the incarnation of the Logos, thus, Christ became human for the purpose of saving humanity from sin. Humanity's sinfulness could be traced to the early chapters of Genesis (especially $1-3$ ) which account for the origin of sin in human history. Sin entered the human world when Satan, acting through the serpent, deceived Adam and Eve to eat a particular fruit which God had commanded them not to eat (see Gen. $2: 17 ; 3: 1-15$ ). In addition to the adverse effect that this act had on humanhuman, human-divine, and human-environment relations, it resulted in the universal pollution of the entire human race with sinful nature, a fact that theologians refer to as original sin (see Ps. 51:5; Rom. 5:12). God's love and mercy demanded that he reconciles himself with humanity. But at the same time, his holy and just nature could not allow this reconciliation without first of all dealing with human sin. The incarnation was the means by which Christ came as human, lived on earth and finally died on the cross to atone for human sin. On the cross, Christ being true human, was a perfect representation for humanity and being true God, was able to offer a perfect sacrifice for the complete redemption of humanity. It was the incarnation that made it possible for Christ to have two natures and hence made it possible to save humanity.

\section{The Atoning Death on the Cross}

By saying that "He [Christ] died on the cross, not spared" (line 3 of stanza one), the hymnist makes the point that since Christ did not do anything to deserve death, it is natural to think that his Father would spare him of death. Contrary to this thought, God's love for the world (humanity) was so deep that he could not spare his Son; he provided Christ as an expiatory sacrifice on the cross (Rom. 3:25). In this line, the hymnist also contends for the trustworthiness of the biblical account of the physical death of Christ- Christ actually died on the cross. This assertion is a polemic against any theory that denies that Christ died physically on the cross. The swoon theory, for instance, claims that Christ did not die in the process of crucifixion; he only fainted (swooned or went into coma) due to the shock, pain and loss of blood and revived or resuscitated after several hours. For the hymnist, the swoon and other theories that contradict the biblical account of Christ's death are false and must be disregarded. Christ died literally on the cross, he was not spared.

\section{God's Invitation and Human Response}

\footnotetext{
Frederick M. Amevenku and Isaac Boaheng, Essays in Exegetical Christology (Accra: Noyam Publishers, 2020), 51-55.

10 The word "man" is used generically to refer to humanity in general.
} 
The last line of the first stanza, "To save the repentant man," highlights both the reason for Christ's atoning death and the condition for one to benefit from this sacrificial death. Though the cross signifies the saving act of God, not everybody will benefit from the event that took place on it. The salvific benefits of the cross are made available to those who repent of their sins, confess their sins and accept (by faith) the sacrifice made on their behalf. The gospel message is freely offered to everyone, and whoever turns away from the world and comes to Christ will be saved.

For the hymnist:

Humanity must respond

To such love shown by the Lord

For salvation is a bond

That brings man close to the Lord (stanza 4)

In this stanza, the hymnist contends that humanity must respond to God's provision made through the cross. Before the cross, humanity was God's 'enemy' but the cross has now reconciled God with humanity in an everlasting bond. Therefore, Christ's death changes the situation whereby sinful Adam hid away from God in the Garden of Eden (Gen. 3:9) to a situation where humanity lives in the presence of God.

When one repents and through faith accepts Christ's sacrifice on the cross and then lives in accordance with the commandments of God, the ultimate destiny of such a person is to spend eternity in heaven. That is why the hymnist, in lines 3 and 4 of stanza 2 respectively, says Christ came "To live as God in the flesh, To make heaven our own home."

The hymnist alludes to God's invitation to all humanity when he writes:

Sinners are always welcome

To the mercy seat of God

The Lord makes us overcome

The moment we come to God (stanza 4)

Here, the point is made that until a person dies, no time is too late for salvation. "Sinners are always welcome" underlines God's invitation to all humanity at all places and at all times. God does not want anyone to be lost and so he is inviting everyone to the cross regardless of a person's situation. Having been saved, the believer is given the grace that makes him/ her an overcomer in life.

\section{God's Love as a Paradigm for Human Love}

The refrain of the hymn reads:

Love that made him overcome

We strive for such wondrous love

Love that is unconditional [incarnational]

Love that heals the broken heart

The refrain begins with the line "Love that made him overcome" which is the hymnist's way of saying "It is love that made him overcome." Here, the hymnist contends that love was the main motivation for which Christ condescended (descended to a lower state). Therefore, believers must emulate this love. The statement "Without love he could not come" (line 2 of stanza 2) reminisces Romans 5 where Paul talks about God's love which came at the right time when humans were powerless and could do nothing to save themselves (cf. vv. 6-8). It was not easy to accept the task of becoming the sacrificial victim for the sins committed by humanity. However, Christ's love for humanity overcame any barrier that could have prevented him from saving humanity. C. S. Lewis justifies this point with the following quote: "God did not die for man because of some value he perceived in him. The value of each human soul considered simply in itself, out of relation to God, is zero. ... to have died for valuable men would have been not divine but merely heroic; but God died for sinners. He loved us not because we were lovable, but because he is love."11

Christianity is about becoming like Christ and Christlikeness requires one to emulate the love of Christ. This point is highlighted in the line "We strive for such wondrous love." Every true Christian strives to have this kind of love, the kind of love that makes one prioritize the interest of others. Christian love must be agape, the highest level of love one can offer. Agape love is unconditional and hence it is given without any expectations of receiving anything in return. Such love is not only unconditional but also incarnational, meaning Christian love must be demonstrated practically.

\section{Pneumatological Reflections on "Come Holy Spirit Come now"}

"Come Holy Spirit Come now" was written as the hymnist's theology reflections on Wesleyan pneumatology as depicted

\footnotetext{
11 Wayne Martindale and Jerry Roots (eds.), The Quotable Lewis (Wheaton: Tyndale House publishers, 1990), 254
} 
in a number of Wesley's works. ${ }^{12}$ The lyrics read are follows:

\section{First stanza}

Come Holy Spirit come now,

Come and fill us all now

Spirit of life, Spirit of joy,

Come and fill us anew.

\section{Second stanza}

Though we are like lifeless bones;

Come and revive your own:

Spirit of life, Spirit of joy,

Come and fill us anew.

\section{Third stanza}

Do not leave us fatherless;

We need you, no less

Spirit of life, Spirit of joy,

Come and fill us anew.

\section{Fourth stanza}

Now pour your power on us all;

For we need it once more;

Spirit of life, Spirit of joy,

Come and fill us anew.

\section{The Identity of the Holy Spirit}

An appropriate point to start the exposition of this hymn is to ask the question: Who is the Holy Spirit? The word "Holy" comes from the Hebrew word kadosh (Greek: hagios) which implies sacredness. The holiness of the Spirit stresses perfect righteousness, as well as majesty and glory. The word "spirit" translates the Hebrew word ruach (Greek: pneuma; Latin: spiritus). "Spirit" carries the idea of intangibility, incorporeality (or immateriality), freedom of movement, power, among others. The article "the" highlights specificity, singularity and uniqueness. Though angels and (inner) humans are spirits, and may be regarded as "holy angels" (Mark 8:38) or holy means, no such holy spirit can be referred to as "the Holy Spirit." Theologically, the Holy Spirit is the third person in the Trinity.

\section{The Promise is for all Christians}

In the Old Testament era, the Holy Spirit came upon people to perform certain divine assignments and then left them afterward (cf. Num. 11:16-17; 1 Sam. 16:14; Ps. 51:11). Thus, the Holy Spirit had no permanent dwelling in humans. God, through the prophet Joel, promised the pouring of his Spirit upon all flesh, saying, "And afterward, I will pour out my Spirit on all people. Your sons and daughters will prophesy, your old men will dream dreams, your young men will see visions" $(2: 28, \mathrm{NIV})$. John the Baptist alluded to the fulfillment of this prophecy when he said that Christ will baptize with the Holy Spirit and fire (Matt. 3:11). Jesus also gave a number of prophecies about the Holy Spirit (see John 14:16, 26).

Joel's prophecy was fulfilled on the Day of Pentecost when the Holy Spirit came upon the disciples in the form of tongues of fire (Acts 2:3). "All of them were filled with the Holy Spirit and began to speak in other tongues as the Spirit enabled them" (Acts 2:4). Responding to the accusation that the disciples' behavior under the power of the Spirit was due to their drunk state (Acts 2:13), Peter connected what had happened to Joel's prophecy (Acts 2:14-41, esp. v. 16). Of great importance to the present discussion is Peter's assertion that "The promise is for you and your children and for all who are far off-for all whom the Lord our God will call." (Acts 2:39, NIV) This means that Christians of every generation and every place may experience the power of the Holy Spirit. God's gift of the Holy Spirit was not for the early Christians alone but "for all whom the Lord our God will call." The hymnist therefore, writes, "Come Holy Spirit come now, Come and fill us all now" with the conviction that whoever asks God for the Holy Spirit will receive him (see Luke 11:13).

\footnotetext{
12 The harmonization was done with the help of Mr. Isaac K. Gyau.
} 


\section{Pneumatological Revivification in the Graveyard: Can Dry Bones live again?}

The second stanza reads in part, "Though we are like lifeless bones; Come and revive your own." These lines allude to Ezekiel's vision in Ezekiel 37. The book of Ezekiel (and particularly chapter 37) may be described as "an earnest attempt to persuade a despairing audience to envision themselves as part of a future blessed by God, and to that end, to embrace their role in the restoration of national life"13 The chapter is part of a larger unit (chs. 34 to 48) which gives hope of restoration to the exilic descendants of Abraham because of God's covenant fidelity and mercy. The context of Ezekiel 37 presents the depressing and hopeless state of exilic Jews. Israel's hopelessness is depicted by disjointed human bones without flesh, breath or life (see Ezek. 37:11). The people had been exiled because they sinned and rejected YHWH, their God. In exile, they now thought their end had come. The merciful God, however, used this vision to assure them that they would not be enslaved forever; they would return home and live again.

Some theological thoughts expressed in Ezekiel 37:1-14 which apply to the hymn "Come Holy Spirit come now" can be noted and outlined. Firstly, there is theology of divine presence in Ezekiel's use of expressions "the hand of YHWH" (37:1; see also 1:3; 3:22; 8:1, 3; 40:1) , and "the Spirit of YHWH" (37:1, 14; see also 2:2; 3:12, 14, 24; 8:3; 11:1, 2, 5, 24; $36: 27 ; 39: 29 ; 43: 5$ ). Secondly, there is a resurrection theology (cf. vv. 7-10) indicated by "the rattling sound of the bones, their coming together, their having tendons and clothing with flesh, their being covered with skin in response to the prophetic declaration." ${ }^{4}$ The twofold act of speaking the Word to have the dry bone form skeletons covered with tendons and flesh (vv. 7-8) and the breathing of the breath of life to revive and resurrect the bodily forms into living humans reversed the lifeless and hopeless condition of the dry bones. Thirdly, there is a restorative theology indicated by YHWH's promise of a divine futuristic action (vv. 11-14). Fourthly, there is a recognition theology indicated by the recognition/ acknowledgment formula, "you will know/they will know" (vv. 5-6, 13-14). Fifthly, the whole episode highlights the sovereignty of YHWH. When the Spirit moves, his greatness, power, and supreme authority is acknowledged. Sixthly, Ezekiel's vision shows the need to balance the Word (v. 4) with the Spirit (v.9). Any theology that does not have this balance is not worth it's salt.

Like Ezekiel's Israel, the contemporary society has ignored it's poor whilst it oppresses them and preys upon them; sexual immorality abounds; true worship has been replaced with a hodgepodge and the church has become a grave of dry bones. The world needs the quickening of the Holy Spirit. In such a situation the hymnist gives hope: "A revival is possible! Even dry bones, without sinews, flesh and blood, can live." Just as God reconstituted the body and revived these corpses by his Spirit, so the hymnist petitions the Spirit for individual restoration, and national rebirth and regathering.

"The coming of God's Spirit brings life." ${ }^{15}$ It is in the light of this life-giving character of the Spirit that the hymnist refers to the Spirit as "Spirit of life" (Rom. 8:2). In the context of Romans 8:2, the life Paul's point to is that the "the Spirit of life" gives life to believers both in the present-through justification (which redeems them from the penalty of their sin) and sanctification which saves them from the power of sin-and in the future (through the resurrection of the dead). This is exactly the hymnist's message: "May God's Spirit renew us restore our broken relationship with God." The restoration of the human relationship with God through the Spirit brings great joy and so the hymnist rightly calls the Spirit "Spirit of joy."

\section{Infilling of the Holy Spirit}

Believers are distinguished from unbelievers as those who have been born again, who have received eternal life, who are indwelt by the Holy Spirit and are sealed by the Holy Spirit. The Holy Spirit baptizes and dwells in a person at the moment of conversion. ${ }^{16}$ Related to the Holy Spirit baptism is the infilling of the Holy Spirit. In relation to this, the following lines run through each stanza of the hymn: "Spirit of life, Spirit of joy, Come and fill us anew." In addition to the above lines are the petitions: "Now pour your power on us all; For we need it once more" (stanza 3 lines 1 and 2). Paul says, "Do not get drunk on wine, which leads to debauchery. Instead, be filled with the Spirit" (Eph. 5:18, NIV). The Greek verb translated "be filled" is the present passive imperative of the verb pleroo indicating the continual action, thus, the believer has the responsibility to keep being filled by the Spirit. Being filled with or being full of the Holy Spirit "points to that dimension of the Spirit's bestowal that relates to interiority, that is to say, the whole community or person is inwardly pervaded by the Holy Spirit." 17

Asking God to fill one with the Holy Spirit anew, does not literally mean asking for more of the Holy Spirit as if the Holy Spirit can be received in parts. Rather, it means the Holy Spirit getting more of the believer. When

\footnotetext{
13 Jacqueline E Lapsley, Can These Bones Live? The Problem of the Moral Self in the Book of Ezekiel (Berlin; New York: Walter de Gruyter, 2000$), 2$.

14 Joel Kamsen Tihitshak Biwul, “The Restoration of the 'Dry Bones' in Ezekiel 37:1-14: An Exegetical and Theological Analysis,” Scriptura 118 (2019:1):110,6 .

15 Yates cited by William MacDonald, Believer's Bible Commentary edited by Art Farstad (Nashville, TN: Thomson Nelson Publish-ers, 1990), 1063.

16 There is also the view that Holy Spirit baptism comes after conversion. This paper is not meant for the debate involved.

17 J. Rodman Williams, Renewal Theology: Systematic Theology from a Charismatic Perspective vol. 2 (Grand Rapids, MI: Zondervan, 1996 ), 202.
} 
one asks for the "refilling" of the Holy Spirit it means the believer is asking that the Holy Spirit dwelling in him/ her already should increase his control over the person. This means that the person is now going to yield more (or completely) to the Holy Spirit's direction. At the same time, the hymnist uses the line "fill us anew" to ask for greater empowerment of the Holy Spirit for divine assignments. The petitioner is saying that the Holy Spirit, who has now been given free access to the whole being, fills all those areas in lives that had once been closed off. Therefore, being filled anew means having the Holy Spirit increase his control over one's life and/or having more power from the Holy Spirit for ministry. In this sense, one can understand filling with the Holy Spirit, not as a one-time event but an event that can be repeated in a believer's life. The example of Peter who was filled with the Holy Spirit (Acts 2:4) but was again filled with the Spirit before the Sanhedrin (4:8) and also filled with the Spirit together with other disciples during a prayer session (4:31) seems to highlight the possibility of being filled with the Holy Spirit over and over, says Grudem. ${ }^{18}$ It is also important to note that one can talk of being filled anew when the Spirit uses him/her in a special way as an instrument of God's work on earth. J. Rodman Williams posits that "the experience of being filled may occur afresh by God's sovereign action and in response to new situations. However, any renewed filling is against the background of the original breakthrough of God's Spirit when the Spirit moved throughout and all barriers were broken down" because "the Holy Spirit is free to move again and again, as all of life becomes redolent with the presence and wonder of Almighty God."19

A number of important results come when a person is filled with the Spirit. First, being filled with the Holy Spirit leads to progressive sanctification. Wesley considered the Spirit as the "immediate cause of all holiness" in the believer and as "God's gracious empowering presence restored through Christ." ${ }^{20}$ A Spirit-filled Christian is equipped and empowered to serve and to live a holy life. Second, a Spirit-filled Christian bears the fruit of the Spirit including love, joy, peace, patience, kindness, goodness, faithfulness, gentleness and self-control (Gal. 5:22-23). Thus, the infilling of the Spirit produces a character-transforming fruit that every Christian must bear. Third, in addition to its transformative effect, the infilling of the Holy Spirit also endows believers with spiritual gifts (or gifts of grace) (see 1 Cor. 12). More so, a Spirit-filled Christian receives guidance from the Holy Spirit as well as an assurance of salvation (Rom. 8:14, 16). The result of the fullness of the Spirit is renewed fellowship and thanksgiving (Eph. 5:19-20).

\section{Towards an African Christian Theology of Mission}

Based on the theological reflections given above the study proceeds to formulate a theology of mission for the African Church.

\section{Mission as a Trinitarian Task}

The Triune God is the source of all Christian missions. Mission does not originate from humans, but from God. According to Moltmann "It is not the church that has a mission of salvation to fulfil in the world; it is the mission of the Son and the Spirit through the Father that includes the church." ${ }^{21}$ Mission is thereby a movement from God to the world. In the process, God uses the church as an instrument. The plan of mission "flows from 'fountain-like love,' the love of God the Father."22 God the Father planned the rescue mission, he sent the Son and the Holy Spirit to help the Church to accomplish her part.

God exhibited his missionary nature when he came looking for Adam in the Garden of Eden after the Fall (Gen. 3). God came searching and asking "Where are you?" (v. 9). Throughout the history of the Church God is seen as initiating acts of reconciliation between himself and fallen humanity. It is his nature to relate, reconcile and redeem. God's missionary nature is also evident in his acts of delivering Israel from their Egyptian bondage based on his eternal attribute of love (Ex. 3:1-14; 20:1; 34:6-7). God alluded to his reconciling mission in all generation when he said to Israel "You yourselves have seen what I did to Egypt, and how I carried you on eagles' wings and brought you to myself." (Ex. 19:4, NIV, emphasis mine)

The Father sent Jesus to achieve a salvific purpose. Jesus preached the message of the kingdom of God (Matt. 3:2, 11; cf. Mark 1:15). He revealed his salvific agenda in Luke 4:18-19. More importantly, Jesus, through His atoning sacrifice on the cross, became the message of mission. The early church preached Christ, the good news about Jesus and the resurrection (cf. Acts $5: 42 ; 8: 5,35 ; 11: 20 ; 17: 18$ ). Key aspects of Christian proclamation-including "the sinfulness of humanity and the need for repentance, prophecies about the coming Messiah, the miracles and teaching of Jesus, the Christ, the atoning sacrifice of Jesus on the cross of Calvary, Jesus' physical resurrection, the

\footnotetext{
Wayne A. Grudem, Systematic Theology: Introduction to Christian Doctrine (Nottingham: Inter-Varsity Press, 2011$), 782$.

Williams, Renewal Theology, 203.

Randy L. Maddox, Responsible Grace: John Wesley's Practical Theology (Nashville: Kingswood Books, 1994$), 120$.

Jurgen Moltman, The Church in the Power of the Spirit: A Contribution to Messianic Ecclesiology (London: SCM Press, 1977$), 64$.

Geoffrey Wainwright, Embracing Purpose: Essays on God, the World and the Church (Eugene, OR: Wipf and Stock, 2007$), 68$.
} 
sending of the Holy Spirit, and the promise of the Parousia" (cf. Acts 2:14-42; 10:34-43; 26:1-29; 1 Cor. 15:1-5) ${ }^{23}$ -are all Christocentric. There is therefore no mission without Christ and his works.

Prior to his ascension Jesus told his disciples to wait in Jerusalem until they have been clothed with power from on high (Luke 24:49) to "be my witnesses in Jerusalem, and in all Judea and Samaria, and to the ends of the earth"(Acts 1:8, NIV). Instead of political dynamis (power), formerly sought by his disciples (Acts 1:6), Jesus promised them a far greater power meant for missions. By this promise, Jesus was making the point that God's Spirit is behind his mission. The Holy Spirit is the power of the Christian mission. In the book of Acts Luke talks so much about the work of the Holy Spirit in God's mission to the extent that the book of Acts might rightly be referred to as the Acts of the Holy Spirit. On the Day of Pentecost when the Church was born, it was the Spirit who empowered the disciples to carry the gospel message from Jerusalem to other parts of the world. ${ }^{24}$ The Spirit sets aside leaders for mission (Acts 13:1-4) and opens and closes doors (cf. Acts 16). To sum up, God continues to carry out and guide his mission through the Holy Spirit.

The theocentric dimension of Christian mission has some implications. Firstly, since mission originates from God, it should not be ignored by the Church. The Church must be involved in mission because by doing mission the church lives according to the will and purpose of God. Secondly, because it is God who has given the Church a missionary task, he will equip the Church for the task. Therefore, those who feel inadequate should be rest assured that God will empower them to complete their part of the task. Thirdly, since mission is God's activity through humans, no one should undertake God's mission for self-glorification. Rather, it is God who should be glorified in all Christian endeavors. Fourth, if Christian mission is God's own activity then it will definitely succeed because God cannot fail. This however does not mean everyone to whom the gospel is preached will convert. Rather, it means Christian mission in totality will never be a failure. Fifth, the unity in the Triune God who is the source of Christian mission implies that Christian mission should preserve the unity of the Church. Jesus' priestly prayer (in John 17:21) underlines the need to maintain the same organic unity between Jesus and the Father among believers. Therefore, any missionary endeavor that does not promote unity among Christians must be avoided.

\section{Mission as a Cross-centered Enterprise}

The message of Christian mission is the cross. No message should upsurge the fundamental message of mission, which is the cross. In Africa where poverty looms large, the church should guard against the prosperity theology which in the long run makes Christians focus more on wealth than spiritual and moral transformation. Again, it must be noted that the Holy Spirit is not the core message of Christian mission; he is a helper to those who preach the core message, that is the cross. Baptism and sacraments in general do not also form part of the core message of mission. The point is that in mission, the initial message should aim at bringing hearers to a belief in Christ. This serves as a foundation for broader theological teaching which is done to disciple the convert. Therefore, Christian missionaries in Africa and elsewhere should be careful not to begin with peripherals such as Eucharist, baptism, wealth, among others.

\section{Mission as the Core Mandate of the Church}

B. F. Fubara-Manuel has profoundly asserted that "one of the most troubling misunderstandings of the Church's missional calling is the very common error of regarding mission simply as one of the Church's tasks rather than its very life." ${ }^{25}$ Fubara-Manuel's point is that the Church has one key function, that is mission. Thus, one agrees with Kalu that "A Church has no other reason for existence except mission. Mission is not what the church does but what the church is. Churches should be witnesses, signs, representatives, a foretaste of the presence of the kingdom of God in our communities." ${ }^{26}$ A Church that fails to be in mission fails to live up to the name "Church." It is important to note that "the Church has no mission on its own and is not to undertake anything of its own as such, except that in which God calls it to share."27 Hence, the Church does not own the missio Dei; rather, the Church is called to be a participant in the missio Dei. The fact that mission is not owned and controlled by the Church does not mean that the Church is to fold its arms and watch. Rather, the Church must avail itself to be used as a divine instrument for reaching the world with the gospel.

According to J. Kwabena Asamoah-Gyadu "Anybody who has cared to pay attention to the life of the Church today is likely to see a Church that is committed not to the core business of mission or the things of the Spirit as defined by the Cross, but carnality that manifests in foolish jesting, ecclesiastical pomposity, and the exploitation of the Gospel

\footnotetext{
23 Isaac Boaheng, "Cross-Cultural Christian Mission in the Ghanaian Context: Challenges, Strategies and Prospects." E-Journal of Religious and Theological Studies 6, no.1 (2020): 16-26, 20.

24 Boaheng, "Cross-Cultural Christian Mission in the Ghanaian Context," 18.

25 B. F. Fubara-Manuel, In the Missio Dei: Reflections on the Being and Calling of the Church in the Sovereign Mission of God (Calabar: Presby Press, 2007), 139.

26 Kalu cited in Fubara-Manuel, In the Missio Dei, 140.

27 Fubara-Manuel, In the Missio Dei, 139.
} 
for economic gain." ${ }^{28}$ A reflection on this observation should bring back the Church on track. The Church's missionary enterprise must result in making disciples of all nations. Such a disciple-making task must have a multiplying effect. That is why Tom Nelson says, "If we as a church succeed in every area, but fail to make disciples who can spiritually multiply, then ultimately we have failed. Yet if we fail in every other area, but succeed in spiritual multiplication, then ultimately we have succeeded." 29 The Church should focus on quality rather than quantity. Quality disciples are committed to following Christ fully; they experience radical life transformation and are committed to mission. It must be noted that the survival of the church in years to come depends on how effective it plays its missionary role today. Therefore, the Church must do all it can to succeed in its missionary endeavors.

\section{Mission as Incarnational Agapaō}

That the African experiences daily struggles does not need to be demonstrated because it is regarded as a fact that is known globally. In Africa, people are faced with the challenge of oppression, poverty, injustice, hunger, ethnic conflict, child trafficking, inhuman treatment of prisoners, the neglect of the poor and immorality in the society, among others. In most African countries, says Jonathan A. Aderonmu, poverty manifests itself in "bad roads, women and children walking barefooted and trekking long distances to get water and firewood, pupils studying under trees, dilapidated and ill-equipped health centers and scores of [other] poverty-driven problems." ${ }^{\prime 30}$ The continent is experiencing food insecurity, especially in places such as the Lake Chad Basin, Central African Republic, the Democratic Republic of the Congo, Somalia, and South Sudan. ${ }^{31}$ In many parts of the continent, lack of health facilities results in the death of people whose lives could have been saved. In Ghana for instance a seventy-year-old patient died recently in the process of being transferred from a hospital that lacked beds to a new one where beds could be found. ${ }^{32}$ The HIV/AIDS pandemic has affected Africa more than any other continent, according to reports by the World Health Organization. ${ }^{33}$

Africa is also heavily affected by corruption. Globally, Somalia (an African country) was found to be the most corrupt country according to the 2018 Transparency International report. ${ }^{34}$ According to the same report, the following African countries are among the top-ten corrupt nations: South Sudan (third in the world), Sudan (sixth), Guinea Bissau (seventh), Equatorial Guinea (eighth), and Libya (tenth) Corruption in Africa and elsewhere can be linked to ineffective governance. Delia Rubio (chair of Transparency International) points out that "Corruption is much more likely to flourish where democratic foundations are weak and, as we have seen in many countries, where undemocratic and populist politicians capture democratic institutions and use them to their advantage." 35 The question that these existential challenges raise in the face of the Church's claim that there is a sovereign God behind Christian mission is obvious. It is precisely at this point that the following lines come to play:

Love that made him overcome

We strive for such wondrous love

Love that is unconditional [incarnational]

Love that heals the broken heart

The social dimension of Christian mission becomes evident when the hymnist says the love that Christ demonstrated, and which Christians strive for is incarnational. By describing Christian love as incarnational the hymnist underscores the fact that the love that compels Christians to spread the gospel is one that must also move Christians to undertake some social interventions. R. Keith Whitt describes incarnational love when he says, "Love that is not expressed through the giving of self, practical action and sacrifice is not love. Love must meet the emotional, physical, and spiritual needs of those loved. It is costly, brings vulnerability, and seeks the person's highest good (1 Cor. 13:4-7)." ${ }^{36}$

The hymnist encourages, instructs and motivates the African church to help relieve people of their plight. For the hymnist, the very profession of Christianity implies the profession to do all that is possible to improve the social, economic, political, and spiritual lives of people. Christian mission will have no or little impact and meaning if it is divorced of social responsibilities. African Christian mission must maintain a balance between its spiritual and social dimensions. This is core to true Christian religion. African missionary activities must give hope to those in the pain of

\footnotetext{
28 Johnson Kwabena Asamoah-Gyadu, Jesus our Immanuel (Accra: African Christian Press, 2012), 140.

29 Tom Nelson as cited by Jude Hama, "Rethinking the Great Commission: Calling the Church Back to Authentic Disciple-Making Ministry" in Rethinking the Great Commission: Emerging African Perspectives edited by Emmanuel Asante and DNA Kpobi (Accra: Type Company Limited, 2018 ), 116.

30 Jonathan A. Aderonmu, "Local Government and Poverty Eradication in Rural Nigeria," Canadian Social Science 6, no. 5 (2010): $200-208,201$.

31 Isaac Boaheng, Poverty, the Bible and Africa (Carlisle: Langham Publishing, 2020), 42.

32 Delali Adogla-Bessa, “Man, 70, Dies after 7 Hospitals ‘Rejected Him' over Lack of Beds.” Posted 11 June 2018. Accessed 21 May 2020. https://citinewsroom.com.

WHO, HIV/AIDS, accessed August 8, 2021. https://www.afro.who.int/health-topics/hivaids

34 Transparency International, Corruption Perceptions Index 2018 (Berlin: Transparency International, 2019$), 1$.

35 Transparency International, Corruption Perceptions Index, 1.

36 R. Keith Whitt, "What Does it Mean That God's Love Is Unconditional?" (2019), accessed August 25, 2020.

https://www.biblestudytools.com/bible-study/topical-studies/the-unconditional-love-of-god.html.
} 
poverty, injustice, diseases, and all other forms of difficulties that such maladies "do not hold the last word in human history." 37

The Church must use her prophetic voice to speak for the voiceless and to combat oppression, injustice and unbiblical political principles and practices. The hymnist's call to demonstrate incarnational love in Christian mission is therefore, "an automatic call to social justice, advocacy in economic and political matters, and to ecological integrity." 38 Following Jesus' example (cf. Luke 4:18-19; Matt. 14:13-21), the church must show great interest in the life of the marginalized and participate in the brokenness of the world. ${ }^{39}$

The African communal worldview can facilitate the Church's effort in making Christian love incarnate in African societies. In African primal life and thought priority is given to relationships, sacrifice for others, unity, peaceful co-existence, co-operation, hospitality and inclusiveness, among others. The African communal worldview ensures interdependence and sharing of resources which in effect helps relieve people of their plight. The idea that a person does not live in isolation from the rest of humanity is expressed differently in different African societies. The Akan of Ghana, for instance, highlights their preference for communal life in the saying "I am related by blood, therefore, I exist or I exist because I belong to a family." ${ }^{\prime 0}$

The Akan belief in a universal bond of sharing that connects all humanity corresponds to the Ubuntu philosophy of "I am because you are, you are because I am." This African identity must be developed and promoted to help make the Christian gospel relevant to Africans. Any attempt to import individualistic Christianity from other parts of the globe should be shown the red flag. For example, the un-African and unbiblical prosperity gospel that has become very popular in African Christianity must be rejected because it shifts "emphasis from God's covenantal and communal actions to individual participation in their communal actions." ${ }^{\prime 1}$

The theological message of the hymnist enjoins Christians to reject any form of a "me" theology and rather embrace and develop an "us" theology that seeks the welfare of the entire community rather than the welfare of a selected few. In totality, the hymnist's point is that for Christian love to be incarnational, the African church must see beyond the individual to the whole.

\section{CONCLUDING IMPLICATIONS}

This paper has explored the theological message embedded in two selected hymns_-"The incarnate God appeared" and "Come Holy Spirit, come now" - and then used the theological findings to formulate an African Christian theology of missions based on thematic areas such as the trinitarian dimension of mission, the centrality of the cross in mission, mission as the core mandate of the Church and mission as incarnational agapaō. Based on the entire study, the following conclusions can be made regarding Christian mission. First, hymns can be used to facilitate the propagation of the Christian gospel. Second, the church must sing hymns of high theological value because the theology of a church is informed by its hymns. Third, contemporary theologians must take up the challenge of adding to the Church's hymns so that issue of contemporary relevance can be addressed in the Church's hymns. Thus, Christian mission in Africa must endeavor to address the existential issue in African societies. It is by so doing that the Christian mission will be meaningful and relevant to Africans.

\section{ABOUT AUTHOR}

Isaac Boaheng (Rev.) is an ordained minister of the Methodist Church Ghana serving the Nkwabeng Circuit of the Sunyani Diocese. Boaheng also serves as a Research Fellow at the Department of Biblical and Religious Studies, University of the Free State, South Africa.

\section{BIBLIOGRAPHY}

Aderonmu, Jonathan A. "Local Government and Poverty Eradication in Rural Nigeria," Canadian Social Science 6, no. 5 (2010): 200-208.

Adogla-Bessa, Delali. “Man, 70, Dies after 7 Hospitals ‘Rejected Him’ over Lack of Beds.” Posted 11 June 2018. Accessed 21 May 2020.

https://citinewsroom.com/2018/06/man-70-dies-after-7-hospitals-rejected-him-over-lack-of-beds/

Amevenku, Frederick M. and Isaac Boaheng, Essays in Exegetical Christology. Accra: Noyam Publishers, 2020.

\footnotetext{
7 Fubara-Manuel, In the Missio Dei, 230.

38 Fubara-Manuel, In the Missio Dei, 230.

39 John Stott, Issues facing Christians Today. 4th ed. (Grand Rapids: Zondervan. 2006), 24.

$40 \quad$ John S. Pobee, Towards an African Theology (Nashville: Abingdon, 1979), 49.

41 Fubara-Manuel, In the Missio Dei, 231.
} 
Asamoah-Gyadu, J. Kwabena. Jesus our Immanuel. Accra: African Christian Press, 2012.

Biwul, Joel Kamsen Tihitshak. "The Restoration of the 'Dry Bones' in Ezekiel 37:1-14: An Exegetical and Theological Analysis," Scriptura 118 (2019:1):1-10, 6. http://dx.doi.org/10.7833/118-1-1528

Boaheng, Isaac. "Cross-Cultural Christian Mission in the Ghanaian Context:Challenges, Strategies and Prospects." E-Journal of Religious and Theological Studies 6, no.1 (2020): 16-26.

. Poverty, the Bible and Africa. Carlisle: Langham Publishing, 2020.

Fubara-Manuel, B. F. In the Missio Dei: Reflections on the Being and Calling of the Church in the Sovereign Mission of God. Calabar: Presby Press, 2007.

Grudem, Wayne A. Systematic Theology: Introduction to Christian Doctrine. Nottingham: Inter-Varsity Press, 2011.

Hama, Jude. "Rethinking the Great Commission: Calling the Church Back to Authentic Disciple-Making Ministry" in Rethinking the Great Commission: Emerging African Perspectives edited by Emmanuel Asante and DNA Kpobi. Accra: Type Company Limited, 2018.

Lapsley, Jacqueline E. Can These Bones Live? The Problem of the Moral Self in the Book of Ezekiel. Berlin; New York: Walter de Gruyter, 2000.

MacDonald, William. Believer's Bible Commentary edited by Art Farstad (Nashville, TN: Thomson Nelson Publishers, 1990.

Maddox, Randy L. Responsible Grace: John Wesley's Practical Theology. Nashville: Kingswood Books, 1994.

Martindale, Wayne and Jerry Roots (eds.), The Quotable Lewis. Wheaton: Tyndale House Publishers, 1990.

Moltman, Jurgen. The Church in the Power of the Spirit: A Contribution to Messianic Ecclesiology. London: SCM Press, 1977.

Park, Andy. To Know You More: Cultivating the Heart of the Worship Leader. Downer Grove, IL: Inter-Varsity Press, 2004.

Pobee, John S. Towards an African Theology. Nashville: Abingdon, 1979.

Stott, John. Issues facing Christians Today. 4th ed. Grand Rapids: Zondervan, 2006.

Transparency International, Corruption Perceptions Index 2018. Berlin: Transparency International, 2019.

Wainwright, Geoffrey. Embracing Purpose: Essays on God, the World and the Church. Eugene, OR: Wipf and Stock, 2007.

Whitt, R. Keith. "What Does it Mean That God's Love Is Unconditional?" 2019.Accessed August 25, 2020. https://www.biblestudytools.com/bible-study/topical-studies/the-unconditional-love-of-god.html.

Williams, J. Rodman. Renewal Theology: Systematic Theology from a Charismatic Perspective vol. 2. Grand Rapids, MI: Zondervan, 1996. 


\section{APPENDIX}

\section{COME, HOLY SPIRIT COME}

Tine: Inspiritional

Mus. 8 words by: Rev. Isaae Boaheng (March,2020) Arr. by: I. K.Gyau
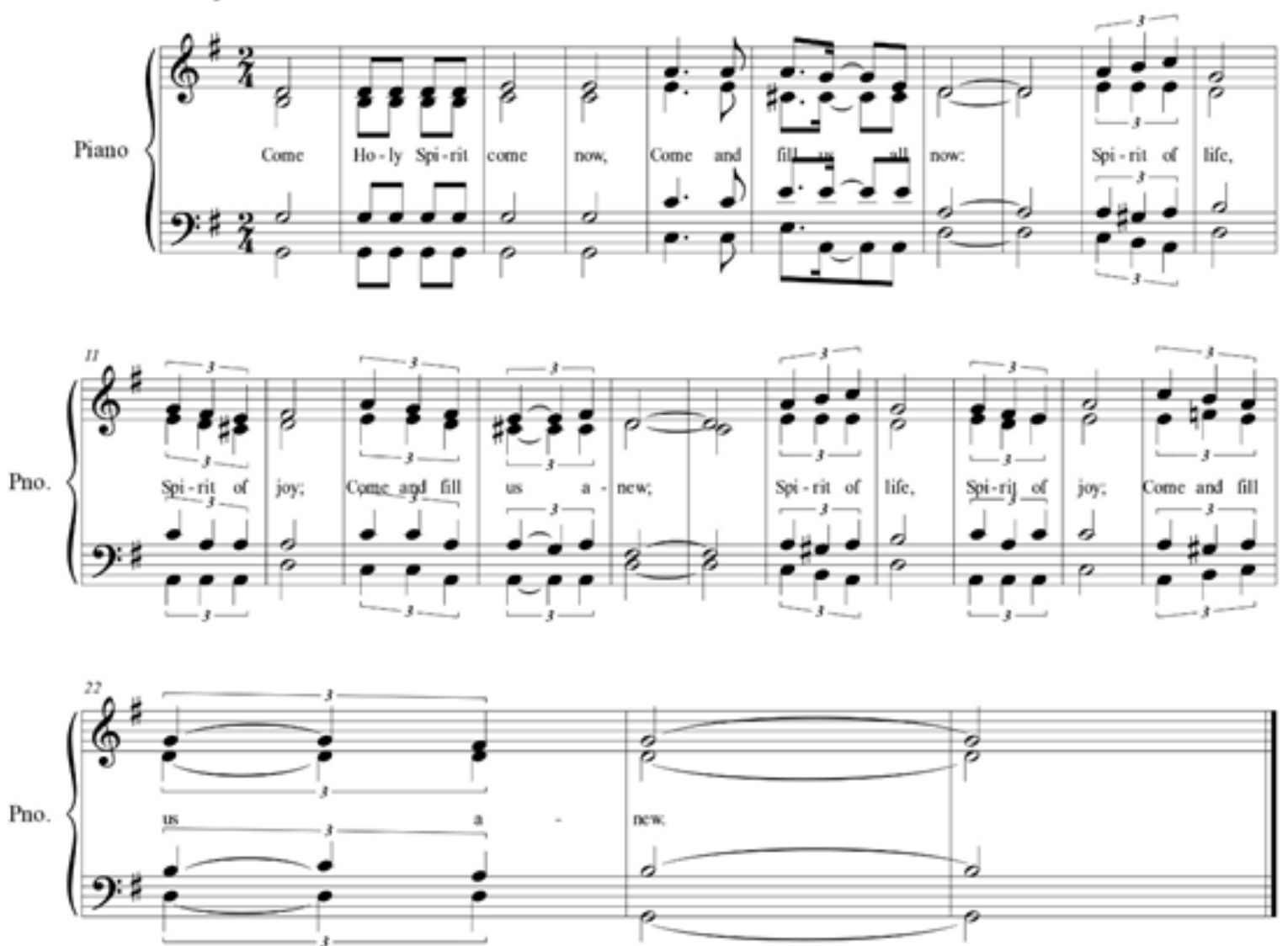

VRS. 2. Though we are like lifeless bone; Come and revive your own: Spirit of life, Spirit of joy, Come and fill us anew.
VRS 3. Do not leave us fatherless;

We need you, no less

Spirit of life, Spirit of joy,

Come and fill us anew.

Vrs 4. Now pour your power on us all;

For we need it once more;

Spirit of life, Spirit of joy,

Come and fill us anew. 


\section{THE INCARNATE GOD APPEARED}

\section{Salvation song}

$\mathrm{Doh}=\mathrm{F}^{\#} / \mathrm{G}$

BY: REV. ISAAC BOAHENG

Tune name: Adu

March 6, 2020

Transcribed by: Mr. Wesley K. Solomon

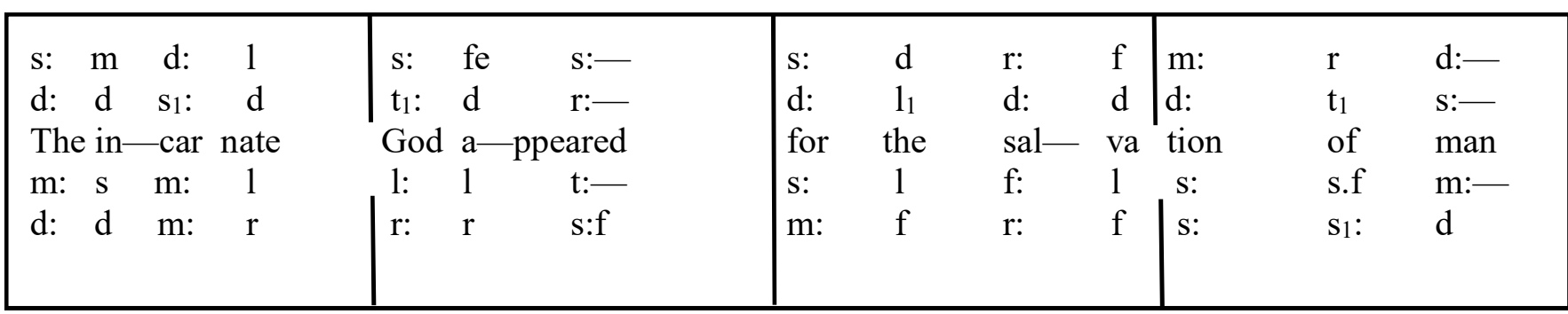

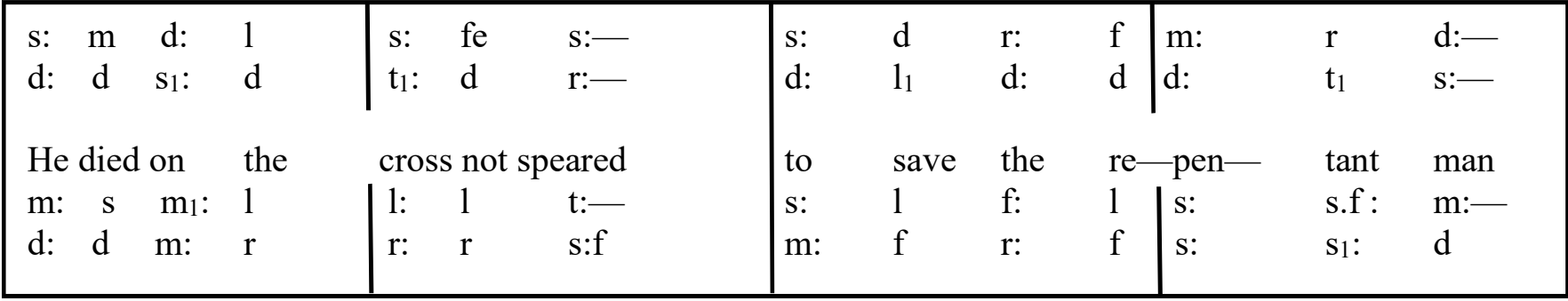

\section{Refrain:}

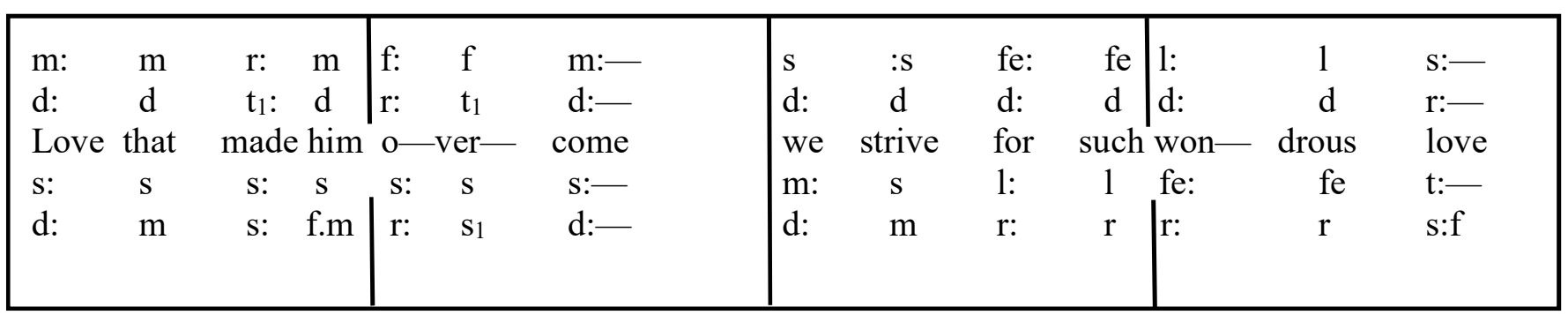




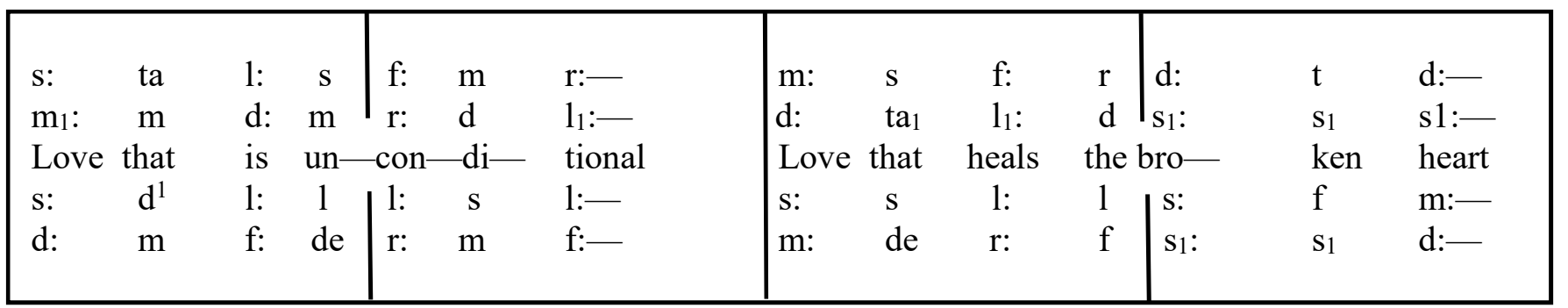

1. The incarnate God appeared

For the salvation of man

He died on the cross, not spared

To save the repentant man

\section{Refrain:}

Love that made him overcome

We strive for such wondrous love

Love that is unconditional

Love that heals the broken heart

2. Christ is God who came in flesh

Without love he could not come

To live as God in the flesh

To make heaven our own home

\section{Refrain:}

Love that made him overcome

We strive for such wondrous love

Love that is incarnational

Love that heals the broken heart
3. Humanity must respond

To such love shown by the Lord

For salvation is a bond

That brings man close to the Lord

\section{Refrain:}

Love that made him overcome

We strive for such wondrous love

Love that is unconditional

Love that heals the broken heart

4. Sinners are always welcome

To the mercy seat of God

The Lord makes us overcome

The moment we come to God

\section{Refrain:}

Love that made him overcome

We strive for such wondrous love

Love that is incarnational

Love that heals the broken heart 